\title{
FASTING ABBREVIATION AMONG PATIENTS SUBMITTED TO ONCOLOGIC SURGERY: SYSTEMATIC REVIEW
}

\author{
Abreviação do jejum entre pacientes submetidos à cirurgia oncológica: revisão sistemática
}

Andressa dos Santos PINTO ${ }^{1}$, Shana Souza GRIGOLETTI ${ }^{1}$, Aline MARCADENTI ${ }^{1,2,3}$.

From the ${ }^{1}$ Instituto de Educação e Pesquisa, Hospital Moinhos de Vento; ${ }^{2}$ Universidade Federal de Ciências da Saúde de Porto

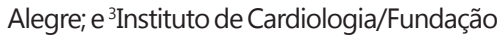
Universitária de Cardiologia ('Education and Research Institute, Moinhos de Vento Hospital; ${ }^{2}$ Federal University of Health Science of Porto Alegre; and Institute of Cardiology/University Foundation of Cardiology), Porto Alegre, RS, Brazil.

HEADINGS - Neoplasms. Diet. Fasting. Surgery.

\section{Correspondence:}

Aline Marcadenti

Email: alinemo@ufcspa.edu.br

Financial source: none

Conflicts of interest: none

Received for publication: 16/04/2014 Accepted for publication: 16/09/2014

DESCRTORES - Neoplasia. Dieta. Jejum. Cirurgia.
ABSTRACT - Introduction: The abbreviation of perioperative fasting among candidates to elective surgery have been associated with shorter hospital stay and decreased postoperative complications. Objective: To conduct a systematic review from randomized controlled trials to detect whether the abbreviation of fasting is beneficial to patients undergoing cancer surgery compared to traditional fasting protocols. Method: A literature search was performed in electronic databases: MEDLINE (PubMed), SciELO, EMBASE and Cochrane, without time restriction. Were used the descriptors: "preoperative fasting", "cancer", "diet restriction" and "perioperative period". Randomized trials were included in adults of both sexes, with diagnosis of cancer. Exclusion criteria were: use of parenteral nutrition and publications in duplicate. All analyzes, selections and data extraction were done blinded manner by independent evaluators. Results: Four studies were included, with a total of 150 patients, 128 with colorectal cancer and 22 gastric cancer. The articles were published from 2006 to 2013. The main outcome measures were heterogeneous, which impaired the unification of the results by means of meta-analysis. Compared to traditional protocols, patients undergoing fasting abbreviation with the administration of fluids containing carbohydrates had improvements in glycemic parameters (fasting glucose and insulin resistance), inflammatory markers (interleukin 6 and 10) and indicators of malnutrition (grip strength hand and CRP/albumin ratio), and shorter hospital stay. The methodological quality of the reviewed articles, however, suggests that the results should be interpreted with caution. Conclusion: The abbreviation of perioperative fasting in patients with neoplasm appears to be beneficial.
RESUMO - Introdução: A abreviação do jejum perioperatório em pacientes candidatos à operações eletivas associa-se com menor tempo de internação hospitalar e diminuição de complicações pósoperatórias. Objetivo: Conduzir uma revisão sistemática a partir de ensaios clínicos randomizados controlados para detectar se a abreviação do jejum traz benefícios para indivíduos submetidos à cirurgia oncológica comparativamente aos protocolos de jejum tradicionais. Método: $\mathrm{A}$ busca na literatura foi realizada nas bases de dados eletrônicas: MEDLINE (Pubmed), Scielo, EMBASE e Cochrane, sem restrição de período. Utilizaram-se os descritores: "preoperative fasting", "cancer", "diet restriction" e "perioperative period". Foram incluídos ensaios clínicos randomizados, em indivíduos adultos, de ambos os sexos, com diagnóstico de câncer. Consideraram-se critérios de exclusão: uso de nutrição parenteral e publicações em duplicata. Todas as análises, seleções e extração dos dados foram feitas de maneira cega por avaliadores de forma independente. Resultados: Foram incluídos quatro artigos, com total de 150 pacientes, sendo 128 com câncer colorretal e 22 câncer gástrico. Os artigos foram publicados no período de 2006 a 2013. Os desfechos principais foram heterogênios, o que impediu a unificação dos resultados por meio de metanálise. Comparativamente aos protocolos tradicionais, os indivíduos submetidos à abreviação do jejum com a administração de líquidos contendo carboidratos tiveram melhora nos parâmetros glicêmicos (glicemia de jejum e resistência a insulina), inflamatórios (interleucina 6 e 10) e nos marcadores de desnutrição (força do aperto de mão e razão PCR/albumina), assim como menor tempo de internação. A qualidade metodológica dos artigos avaliados, porém, sugere que os resultados sejam interpretados com cautela. Conclusão: A abreviação do jejum perioperatório em pacientes com neoplasias parece ser benéfica.

INTRODUCTION

$T$ he malign neoplasias constitute the second cause of death to the Brazilian population, representing almost $17 \%$ of the total deaths. Until 2020 , it is estimated that the worldwide incidence of the disease will be about 15 million especially for the developing countries ${ }^{19}$.

Surgical treatments are considered the first choice in cases of malignancies ${ }^{19}$. However, the nutritional status of the patients with diagnosis of cancer may directly affect the results of the procedure; malnourished individuals submitted to oncologic surgeries have a higher incidence of postoperative complications as well as increased mortality, hospital stay and hospital costs ${ }^{6,8}$

The preoperative nutritional therapy for seven to 14 days is associated with the reduction of postoperative infections and hospital stay ${ }^{13}$, being usually indicated aiming to prevent malnutrition or minimize its effects, as well as to reduce morbidities in the postoperative period ${ }^{1}$. Individuals with indications of elective surgeries are candidates to the preoperative nutritional therapy ${ }^{15,26}$ and both malnourished and well nourished patients were benefited from this conduct ${ }^{11,152,26}$.

The prolonged nightly fasting, instituted in order to prevent lung complications associated to vomiting and aspiration of gastric content may be harmful to the patient ${ }^{4}$. The organic answer to this procedure is aggravated with the operative trauma and the tissue damage that 
follows ${ }^{3}$. Furthermore, the real fasting is often more prolonged than the prescribed fasting, contributing to a worsening of the nutritional status ${ }^{12}$. This way, the premature reintroduction of food in the postoperative period would accelerate the healing and prevent complications related to anastomoses; the benefits of this conduct, however, are still debatable, although protocols developed among populations affected by specific clinical conditions suggest a reduction of the complications due to infections, less hospital stay, early functional recovery and a better response to the surgical treatment ${ }^{22}$

The ingestion of liquids in the immediate preoperative (two to three hours before the surgery) plus carbohydrates seems safe and not related to aspiration, regurgitation or mortality risks comparatively to the patients that remain in traditional fasting protocols, also preventing the dehydration and the thirst $7,9,14,17,24$. The widespread accesion and implementation of this conduct, however, has been low in the clinical practice ${ }^{16}$. Meta-analysis that evaluated 21 clinical studies among patients submitted to non-oncologic surgeries concluded that the preoperative treatment with liquids plus carbohydrates was associated with the reduced hospital stay and improved insulin resistance in large surgeries; however, the studies included were from low to moderate methodological quality 5 .

The purpose of this review was to evaluate the effect of fasting abbreviation among patients submitted to oncologic surgeries compared to the traditional fasting protocols.

\section{METHODS}

This is a systematic review from randomized clinical trials among individuals with malign neoplasias. The search in literature was conducted on the following eletronic databases: MEDLINE (access via Pubmed), Scielo, EMBASE and Cochrane Central Register of Controlled Trials, without time restriction. The descriptors "preoperative fasting", "cancer", "diet restriction" and "perioperative period" were used plus the logical operators "AND" and "OR" for combinations and tracking. Only the texts in English, Portuguese and Spanish languages were considered eligible for analysis. This review was conducted according to the itens established by the Preferred Reporting Items for Systematic Reviews and MetaAnalyses (PRISMA $)^{18}$ and the level of evidence of the selected articles was established by the criteria of the Brazilian Medical Association ${ }^{10}$.

Randomized clinical trails that compared the fasting abbreviation in the perioperative period with the traditional fasting protocol, in adult individuals of both genders and with cancer diagnosis were included. Exclusion criteria were the use of parenteral nutrition and duplicate publications.

The titles and summaries of the selected articleswere evaluated independently by two researchers (ASP e SSG). The reviewers were not blinded to the authors, institutions and journals of the articles. Summaries that provided enough information about the inclusion and exclusion criteria were selected for a complete evaluation of the text. Furthermore, references of the selected articles were redeemed manually. The reviewers independently evaluated the complete articles and settled their eligibility. Disagreements were settled by consensus, and otherwise by a third reviewer (AM). Two reviewers (ASP e SSG) independently conducted the data extraction.

\section{RESULTS}

In total, 504 publications were identified; of these, only 18 articles were randomized clinical trails. After the first analysis, two publications were detected as the same, leaving 16 articles for selection and analysis of titles and summaries. For not presenting the inclusion criteria, only eight articles were considered eligible for a full reading; of these, four were excluded, being one for evaluating parenteral nutrition and three for Eastern language (only the summary was in the English language). In the end, four articles were included in the final analysis and data extraction stage (Figure 1).

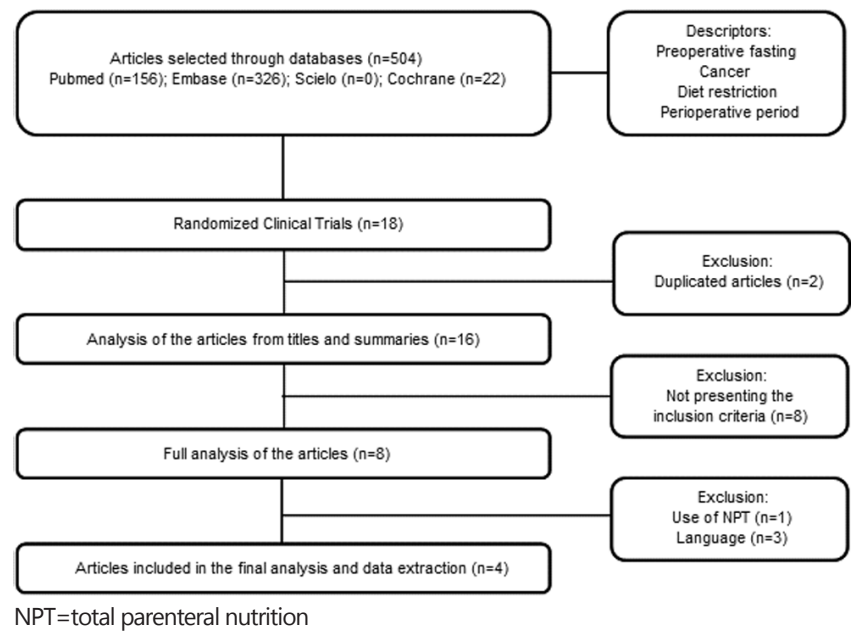

FGURE1 - Flowchart of the identification and data extraction methodology

Table 1 shows the main results of each study. Four articles ${ }^{20,21,25,27}$ that met the inclusion criteria were included, with a total of 150 patients. Of these, 128 presented colorectal cancer ${ }^{20,25,27}$ and 22 had gastric cancer ${ }^{21}$. The articles were published from 2006 to 2013. Only one study was conducted in the Brazilian population ${ }^{21}$, and the others included English, Croatian and Chinese people $20,25,27$.

As for the kind of surgery, the participants of the study $1^{20}$ were submitted to colectomy, sigmoidectomy, anterior resection and abdominoperineal resection. The patients included in the study $2^{25}$ were submitted to right colectomy, anterior resection, panproctocolectomy, proctectomy, sigmoid colectomy and ileocolic resection. In the study $3^{27}$ were presented only ileocolic resections and in the study $4^{21}$ the researchers conducted partial gastrectomy in the allocated individuals.

The fasting abbreviation protocols were similar among the studies, ranging from $800 \mathrm{ml}$ of water containing $12.5 \%$ carbohydrates in the night before the surgical procedure plus 400 $\mathrm{ml}$ of water with the same amount of carbohydrates two to three hours before the anesthesia ${ }^{20,27}$ to $400 \mathrm{ml}$ of water containing $12.5 \%$ carbohydrates three hours before the anesthesia followed ${ }^{25}$ or not $^{21}$ by oral bowel preparation and adeed ${ }^{21}$ or not ${ }^{20,25,27}$ with proteins.

The main outcomes diversified among the studies and included changes in the functional capacity measured by the handgrip strenght, hospital stay, serum glucose, insulin resistance evaluated by the HOMA (Homoeostasis Model Assessment) index and the ISI (Insulin Sensitivity Index), interleukin 6 (IL-6), interleukin 10 (IL-10) leves and C-reactive protein/albumin (CRP/albumin) ratio. Due to the heterogeneity of the studies included, it was impossible to evaluate the results through meta-analysis.

In the study $1^{20}$ researchers concluded that there was a reduction in hospital stay among the patients allocated to the group with fasting abbreviation $(p=0.02)$ as well as a less reduction of the functional capacity measured by handgrip strenght $(p<0.05)$. In the study $2^{25}$, it was observed that the plasma glucose was significantly lower in the group that received liquids followed by carbohydrates in the end of the surgical procedure, compared to the control group ( $p=0.001)$ and to the placebo group $(p=0.002)$; although the HOMA index has significantly increased in the end of the surgery in the three groups, it increased more subtly in the group with fasting abbreviation $(p<0.001)$, as well as the ISI increased in the same period $(p<0.001)$. In the study $3^{27}$, it was verified that the colon resection procedure significantly increased the IL- 6 levels in the 6, 24 and $48 \mathrm{~h}$ after the surgery, being higher among the individuals randomized for the traditional fasting protocol $(p<0.05)$, whereas the patients who received the fasting abbreviation protocol showed significantly higher IL-10 levels $6 \mathrm{~h}$ after the end of the surgery $(p<0.05)$. In the study $4^{21}$ participants allocated to the intervention of carbohydrates adeed with proteins had a significant less hospital stay when compared to the control group ( $p 0.04)$, and the CRP/albumin ratio was significantly higher in the control group 
compared to the intervention group.

The secondary outcomes were also heterogeneous; the evaluations were gastrointestinal function (there was a trend to the premature return of the bowel movement in the patients allocated to liquids with carbohydrates) ${ }^{20}$, thirst, hunger, anxiety, nausea, weariness and weakness (without significant difference among the groups $)^{25,27}$ and glycemic parameters such as blood glucose and serum insulin (increased levels were detected among patients allocated to fasting abbreviation) ${ }^{21}$.

The randomized clinical trials included in this review were classified with level 2 of evidence according to the Oxford criteria adopted by the Brazilian Medical Association, indicating inferior methodological quality due to the lack of information regarding the blinding, allocation and randomization criteria of the individuals as well analysis by intention to treat.

\section{DISCUSSION}

The results of this review suggest that the fasting abbreviation may be beneficial among patients submitted to oncologic surgeries, especially for the abdominal surgeries. The prior administration of liquids containing carbohydrates adeed or not by proteins may result in the decreased hospital stay, improved glycemic parameters after the surgical procedure, modifications in the inflammatory profile and in the functional capacity.

The ERAS (Enhanced Recovery of patients After Surgery) protocol ${ }^{14}$ developed by Europeans has become an important tool in the perioperative management of the patients submitted to elective surgeries, and based the development of other similar protocols in countries as Brazil2. From the metabolic and nutritional point of view, the main aspects suggested by ERAS in the pre and postoperative care after surgical procedures include the caution regarding the prescription of long periods of preoperative fasting, the reestablishment of the oral nutrition as soon as possible after the surgery, the metabolic control of variables such as the serum glucose and the premature mobilization of the patient ${ }^{14}$.

The ACERTO project, a multidisciplinary program developed in Brazil aiming to improve the recovery of the surgical patient ${ }^{2}$, similar to the ERAS protocol, establishes a series of differentiated cares in the pre and postoperative periods. Concerning the fasting abbreviation, in addition to not allowing a prolonged fasting in the preoperative, it suggests the prescription of liquid diet enriched with carbohydrate until the eve of the surgery, considering that this ingestion may take place up to $2 \mathrm{~h}$ before the surgical procedure.

Meta-analyzes indeed seem to establish the superiority of perioperative fasting abbreviation in patients candidate to elective surgeries (especially the abdominal) about the traditional fasting protocols, although the authors themselves acknowledge that the methodological quality of some of the primary studies evaluated was low ${ }^{9,5}$. Clinical guidelines published by several national and international organizations indicate the reduction of preoperative fasting time with drinks rich in carbohydrates and/or clear liquids until a few hours before elective surgeries and even in other situations that require anesthetic procedures ${ }^{15,24,26}$. The Brazilian Society of Parenteral and Enteral Nutrition and the Brazilian Association of Nutrition recommend a fasting period of $6 \mathrm{~h}$ for solids and of $2 \mathrm{~h}$ for clear liquids containing carbohydrates for elective surgeries, as well as the use of maltodextrin at $12.5 \%$ in a volume of $200-400 \mathrm{ml}$, $6 \mathrm{~h}$ and $2 \mathrm{~h}$ before the surgery; they also alert that the prolonged preoperative fasting is unnecessary for most of the patients and that the interruption of the nutritional ingestion is also unnecessary in the postoperative for most individuals ${ }^{15}$.

It is important to emphasize, however, that the minority of the available evidences that support the organization of the guidelines do not discriminate patients with or without cancer, making it difficult

TABLE 1 - Features of the randomized clinical trials analyzed to compare the fasting abbreviation protocol to the traditional fasting protocol in oncologic patients

\begin{tabular}{|c|c|c|c|c|c|c|c|}
\hline $\begin{array}{l}\text { AUTHOR, } \\
\text { YEAR }\end{array}$ & POPULATION & $\begin{array}{l}\text { ABBREVIATED FASTING } \\
\text { PROTOCOL }\end{array}$ & CONTROL & $\begin{array}{c}\text { MAIN } \\
\text { OUTCOME }\end{array}$ & $\begin{array}{l}\text { FOLLOWING } \\
\text { LOSSES }\end{array}$ & RESULT & OLE \\
\hline $\begin{array}{l}\text { Noblett SE, } \\
2006^{19}\end{array}$ & $\begin{array}{c}36 \text { English } \\
\text { people with } \\
\text { colorectal cancer }\end{array}$ & $\begin{array}{c}800 \mathrm{ml} \text { water with } \mathrm{CHO} 12.5 \% \\
\text { at night before the surgery + } \\
400 \mathrm{ml} \text { water with } \mathrm{CHO} 12.5 \% \\
3 \mathrm{~h} \text { before the anesthesia }\end{array}$ & $\begin{array}{l}\text { Control } 1(\mathrm{C} 1): 800 \mathrm{ml} \\
\text { water at night before } \\
\text { the surgery }+400 \mathrm{ml} \\
\text { water } 3 \mathrm{~h} \text { before the } \\
\quad \text { anesthesia } \\
\text { Control } 2 \text { (C2): fasting } \\
\quad \text { from } 24 \mathrm{~h}\end{array}$ & $\begin{array}{c}\text { HS } \\
\text { Hospital stay }\end{array}$ & 1 (water) & $\begin{array}{c}\text { Perioperative until HD: } \\
\text { Hospital stay } \\
\text { C1: } 13 \text { days } \\
\text { C2: } 10 \text { days } \\
\text { CHO: } 7.5 \text { days }(P=0.02) \\
\downarrow \text { HS at } \mathrm{AH} \\
\text { C1: } 8 \% \\
\text { C2: } 11 \% \\
\text { CHO: } 5 \%(P<0.05)\end{array}$ & $2 B$ \\
\hline $\begin{array}{l}\text { Wang ZG, } \\
2010^{25}\end{array}$ & $\begin{array}{c}52 \text { Chinese } \\
\text { people with } \\
\text { colorectal cancer }\end{array}$ & $\begin{array}{c}400 \mathrm{ml} \text { water with } \mathrm{CHO} 12.5 \% \\
\text { 3h before the anesthesia + } \\
\text { oral bowel preparation }\end{array}$ & $\begin{array}{l}\text { Control } 1 \text { (Placebo, } \\
\text { C1): } 400 \text { ml water } \\
\text { + oral bowel } \\
\text { preparation } \\
\text { Control } 2 \text { (C2): nightly } \\
\text { fasting + oral bowel } \\
\text { preparation }\end{array}$ & $\begin{array}{l}\text { Glycemia } \\
\text { HOMA-IR } \\
\text { ISI }\end{array}$ & $\begin{array}{l}2 \mathrm{CHO} \\
1 \text { placebo } \\
1 \text { fasting }\end{array}$ & $\begin{array}{c}\text { In the end of the surgery: } \\
\text { Glycemia } \\
\downarrow \text { significant } \mathrm{CHO} \text { vs. } \mathrm{C}(\mathrm{P}=0.001) \\
\downarrow \text { significant } \mathrm{CHO} \text { vs. } \mathrm{C} 2(\mathrm{P}=0.002) \\
\text { HOMA-IR } \\
\downarrow \text { significant } \mathrm{CHO} \text { vs. } \mathrm{C} 1 \text { vs. } \mathrm{C} 2(\mathrm{P}<0.001) \\
\text { ISI } \\
\uparrow \text { significant } \mathrm{CHO} \text { vs. } \mathrm{C} 1 \text { vs. } \mathrm{C} 2(\mathrm{P}<0.001)\end{array}$ & $2 B$ \\
\hline $\begin{array}{l}\text { Zelic M, } \\
2012^{27}\end{array}$ & $\begin{array}{c}40 \text { Croatian } \\
\text { people with } \\
\text { colorectal cancer }\end{array}$ & $\begin{array}{c}800 \mathrm{ml} \text { water with } \mathrm{CHO}^{*} 12.5 \% \\
\text { at night before the surgery }+ \\
400 \mathrm{ml} \text { water with } \mathrm{CHO}^{*} 12.5 \% \\
2 \mathrm{~h} \text { before the anesthesia } \\
{ }^{*} \mathrm{CHO}: 12 \% \text { monosaccharide, } \\
12 \% \text { disaccharide, } 76 \% \\
\text { polysaccharide }\end{array}$ & $\begin{array}{l}\text { Fasting from } 24 \mathrm{~h} \\
\text { (NPO) }\end{array}$ & $\begin{array}{c}\text { IL-6 } \\
\text { IL-10 }\end{array}$ & No losses & $\begin{array}{c}6 \mathrm{~h} \text { after the surgery: } \\
\text { IL-6 } 169.8 \pm 34.3 \mathrm{NPO} \\
\text { IL-6 } 98.3 \pm 39.3 \mathrm{CHO} \\
(\mathrm{P}<0.05) \\
\text { IL-10 } 38.1 \pm 9.1 \mathrm{CHO} \\
\text { IL-10 } 17.6 \pm 9.1 \mathrm{NPO} \\
(\mathrm{P}<0.05)\end{array}$ & $2 B$ \\
\hline $\begin{array}{l}\text { Pexe- } \\
\text { Machado } \\
\text { PA, } 2013^{20}\end{array}$ & $\begin{array}{l}22 \text { Brazilian } \\
\text { people with } \\
\text { stomach cancer }\end{array}$ & $\begin{array}{c}400 \mathrm{ml} \text { water with } 89 \% \mathrm{CHO}^{*} \\
+11 \% \mathrm{Ptn}^{\star *} \text { at night before } \\
\text { the surgery }+200 \mathrm{ml} \mathrm{CHO*} \\
+11 \% \mathrm{Ptn}^{\star *} 3 \mathrm{~h} \text { before the } \\
\text { anesthesia } \\
\text { CHO*: } 79 \% \text { maltodextrin, } 21 \% \\
\text { saccharose } \\
\text { Ptn**: Protein hydrolyzate protein }\end{array}$ & $\begin{array}{l}\text { Fasting from } 6 \text { to } 8 \\
\text { hours (NPO) }\end{array}$ & $\begin{array}{l}\text { Hospital stay } \\
\text { CRP/albumin } \\
\quad \text { ratio }\end{array}$ & $\begin{array}{c}5 \mathrm{CHO}+\text { Ptn } \\
3 \text { fasting }\end{array}$ & $\begin{array}{c}\text { Hospital stay: } \\
\text { CHO + Ptn: } 7 \text { days } \\
\text { NPO: } 14 \text { days } \\
(p=0.04) \\
\uparrow \text { CRP/albumin ratio NPO vs. CHO } \\
+ \text { Ptn }\end{array}$ & $2 B$ \\
\hline
\end{tabular}

$\mathrm{OLE}=$ Oxford Level of Evidence; $\mathrm{CHO}=$ carbohydrate; $\mathrm{HOMA}-\mathrm{IR}=$ Homoeostasis Model Assessment; ISI= Insulin Sensitivity Index; HS= handgrip strength; HD= hospital discharge; IL-6=interleukin 6; IL-10= interleukin 10; Ptn= protein; NPO: nothing by mouth (fasting) 
the generalization of the results and recommendations. Accordingly, the present review aimed to elucidate if specifically among individuals affected by neoplasic diseases submitted to elective surgeries the benefits of the fasting abbreviation would be the same, independent of the quality of the articles found. The results seem promising, although they must be interpreted with caution due to important methodological issues not being identified from the criteria of the Brazilian Medical Association for classification of the level of evidence. Multicentric clinical trials, in which is possible to include a significant number of participants and strictly follow the criteria proposed by the CONSORT (Consolidated Standards of Reporting Trials) initiative ${ }^{23}$ should be encouraged in order to consolidate the results observed in this review.

Metabolically, long fasting periods result in a reduction of serum insulin levels, and an increase in the glucagon levels and in the insulin resistance. The gluconeogenesis is also a phenomenon that occurs simultaneously to the hormonal changes, raising the endogenous glucose production and consequently raising the serum glucose. High levels of glycogen depletion contribute to the postoperative metabolic stress, that stimulates the cytokine production (interleukins, C-reactive protein) triggered by the tissue damage and exacerbating the insulin resistance ${ }^{17}$. Therefore, the muscle loss (precursor of malnutrition) and the glycemic disorders are important prognostic factors to be observed in the postoperative period. So, the primary trials included in this review that evaluated glycemic indicators (serum glucose, HOMA-IR, ISI ${ }^{25}$, pro/anti-inflammatory tissue damage indicators (interleukins 6 and 10$)^{27}$ and indexes of malnutrition $\left(\mathrm{HS}^{20}\right.$, $\mathrm{CRP} /$ albumin ratio ${ }^{21}$ ) showed satisfactory results regarding the adoption of fasting abbreviation through drinks rich in carbohydrates compared to the standard protocols. Similarly, the hospital stay was lower among the patients allocated to abbreviated fasting ${ }^{20,21}$ corroborating the results obtained through trials that evaluated patients without malignancies ${ }^{2,5}$.

Some limitations of this study are the heterogeneity of the selected articles, which precluded the unification of the results through meta-analysis; the ethnic diversity of the enrolled individuals must also be considered, since the body composition (and consequently the risk for malnutrition) is differentiated in some ethnic groups, especially the Eastern ones. This is an analysis of results already published, and since the authors followed the ethical principles of confidentiality, the formal approval of this review by a research ethics committee is unnecessary.

\section{CONCLUSION}

The fasting abbreviation through the management of liquids containing carbohydrates in patients submitted to oncologic surgical procedures can improve clinical prognostic parameters and reduce hospital stay. The results of this review, however, must be interpreted with caution considering the methodological quality of the evaluated articles. The general fasting abbreviation protocols, however, should be stimulated among the health professionals according to the global benefits already demonstrated in other populations.

\section{REFERENCES}

1. Abunnaja S, Cuviello A, Sanchez JA. Enteral and parenteral nutrition in the perioperative period: state of the art. Nutrients 2013; 5:608-623.

2. Aguilar-Nascimento JE, Bicudo-Salomão A, Caporossi C, Silva RM, Cardoso EA, Santos TP. Acerto pós-operatório: avaliação dos resultados da implantação de um protocolo multidisciplinar de cuidados perioperatórios em cirurgia geral. Rev. Col. Bras. Cir 2006;33:181-188.

3. Aguilar-Nascimento JE, Marra JG, Slhessarenko N, Fontes CJ. Efficacy of National Nosocomial Infection Surveillance score, acute-phase proteins, and interleukin-6 for predicting postoperative infections following major gastrointestinal surgery. Sao Paulo Med J 2007; 125:34-41.

4. Aguilar-Nascimento JE, Perrone F, Prado LIA. Jejum pré-operatório de 8 horas ou de 2 horas: o que revela a evidência? Rev. Col. Bras. Cir 2009; 36:350-352.
5. Associação Médica Brasileira e Conselho Federal de Medicina. Projeto Diretrizes. 2011. Disponível em: http://www.projetodiretrizes.org.br/ projeto_diretrizes/texto_introdutorio.pdf.

6. Awad S, Varadhan KK, Ljungqvist O, Lobo DN. A meta-analysis of randomised controlled trials on preoperative oral carbohydrate treatment in elective surgery. Clinical Nutrition 2013; 32:34-44.

7. Bicudo-SalomaoA,Aguilar-NascimentoJE, CaporossiC.Risconutricional em cirurgia avaliado pelo índice de massa corporal ajustado ou não para pacientes idosos. Arq Gastroenterol 2006; 43:219-223.

8. Bicudo-Salomão A, Meireles MB, Caporossi C, Crotti PLR, AguilarNascimento JE. Impacto do projeto acerto na morbi-mortalidade pósoperatória em um hospital universitário. Rev Col Bras Cir 2011; 38:3-10.

9. Bozzetti F, Gianotti L, Braga M, Di Carlo V, Mariani L. Postoperative complications in gastrointestinal cancer patients: the joint role of the nutritional status and the nutritional support. Clin Nutr 2007;26:698-709.

10. Brady M, Kinn S, Stuart P. Preoperative fasting for adults to prevent perioperative complications. Cochrane Database Syst Rev 2003; (4): CD004423.

11. Cerantola Y, Grass F, Cristaudi A, Demartines N, Schäfer M, Hübner M. Perioperative nutrition in abdominal surgery: recommendations and reality. Gastroenterol Res Pract 2011; 2011:739347.

12. Crenshaw JT, Winslow EH. Preoperative fasting: old habits die hard. Am J Nurs 2002; 102:36-44.

13. de Luis DA, Culebras JM, Aller R, Eiros-Bouza JM. Surgical infection and malnutrition. Nutr Hosp 2014; 30:509-513.

14. Fearon KC, Ljungqvist $\mathrm{O}$, Von Meyenfeldt $\mathrm{M}$, Revhaug $\mathrm{A}$, Dejong $\mathrm{CH}$, Lassen $\mathrm{K}$ et al. Enhanced recovery after surgery: a consensus review of clinical care for patients undergoing colonic resection. Clin Nutr 2005; 24:466-477.

15. InstitutoNacionaldeCâncerJoséAlencarGomesdaSilva. Estimativa2012: incidência de câncer no Brasil [Internet]. Rio de Janeiro: INCA. Disponível em: http://www.inca.gov.br/ estimativa/2012/estimativa20122111.pdf

16. Kehlet $\mathrm{H}$, Wilmore DW. Multimodal strategies to improve surgical outcome. Am J Surg 2002; 183:630-641.

17. Ludwig RB, Paludo J, Fernandes D, Scherer F. Menor tempo de jejum pré-operatório e alimentação precoce no pós-operatório são seguros? ABCD Arq Bras Cir Dig 2013;26:54-58.

18. Moher D, Liberati A, Tetzlaff J, Altman DG; PRISMA Group. Preferred reporting items for systematic reviews and meta-analyses: the PRISMA statement. Ann Intern Med 2009; 151:264-269.

19. Noblett SE, Watson DS, Huong H, Davison B, Hainsworth PJ, Horgan AF. Pre-operative oral carbohydrate loading in colorectal surgery: a randomized controlled trial. Colorectal Dis 2006; 8:563-569.

20. Pexe-Machado PA, de Oliveira BD, Dock-Nascimento DB, AguilarNascimento JE. Shrinking preoperative fast time with maltodextrin and protein hydrolysate in gastrointestinal resections due to cancer. Nutrition 2013; 29:1054-1059.

21. Polakowski CB, Britto JCL, Lopes M, Kato M, Targa GZ. Introdução de dieta precoce no pós-operatório de cirurgias por câncer colorretal: elaboração de um protocolo de dieta. Revista Brasileira de Cancerologia 2012; 58:181-187.

22. Projeto Diretrizes. Terapia Nutricional no Perioperatório. Associação Médica Brasileira (AMB), 2011. Disponível em: http:// www.projetodiretrizes.org.br/9_volume/terapia_nutricional_no_ perioperatorio.pdf

23. Schulz KF, Altman DG, Moher D; CONSORT Group. CONSORT 2010 statement: updated guidelines for reporting parallel group randomized trials. Ann Intern Med 2010; 152:726-732.

24. Smith I, Kranke P, Murat I, Smith A, O'Sullivan G, Søreide E et al. Perioperative fasting in adults and children: guidelines from the European Society of Anaesthesiology. Eur J Anaesthesiol 2011; 28:556569 .

25. Wang ZG, Wang Q Wang WJ, Qin HL. Randomized clinical trial to compare the effects of preoperative oral carbohydrate versus placebo on insulin resistance after colorectal surgery. Br J Surg 2010; 97:317-327.

26. Weimann $A$, Braga $M$, Harsanyi L, Laviano A, Ljungqvist $O$, Soeters $P$ et al. ESPEN Guidelines on Enteral Nutrition: Surgery including Organ Transplantation. Clin Nutr 2006; 25:224-244.

27. Zelic M, Stimac D, Mendrila D, Tokmadzic VS, Fisic E, Uravic M et al. Influence of preoperative oral feeding on stress response after resection for colon cancer. Hepatogastroenterology 2012; 59:1385-1389. 